\title{
Retinoid-Dependent mRNA Expression and Poly-(A) Contents in Bovine Oocytes Meiotically Arrested and/or Matured In Vitro
}

\author{
ENRIQUE GOMEZ, ${ }^{1 *}$ AIDA RODRÍGUEZ, ${ }^{1}$ FELIX GOYACHE, ${ }^{1}$ CARMEN DÍEZ, ${ }^{1}$ LUIS JOSÉ ROYO, ${ }^{1}$ \\ PEDRO N. MOREIRA, ${ }^{2}$ JOSÉ NÉSTOR CAAMAÑO, ${ }^{1}$ ERICA MORÁN, ${ }^{1}$ AND ALFONSO GUTIÉRREZ-ADÁN ${ }^{2}$ \\ ${ }^{1}$ Servicio Regional de Investigación y Desarrollo Agroalimentario (SERIDA), Area de Genética y Reproducción Animal, \\ Camino de los Claveles, 604-Somio, Gijón 33203, Asturias, Spain \\ ${ }^{2}$ Instituto Nacional de Investigación y Tecnología Agraria y Alimentaria (INIA), Departamento de Reproducción \\ Animal y Conservación de Recursos Zoogenéticos, Carretera de La Coruña Km, 5.9, Madrid, Spain
}

\begin{abstract}
The presence of retinoic acid (RA) during in vitro maturation (IVM) improves bovine oocyte quality and developmental potential. In this work, we investigated the underlying molecular mechanisms. Cumulus-oocyte complexes were meiotically arrested by roscovitine and/or matured in defined medium containing RA, $1 \%$ ethanol (vehicle), or no additives. Cumulus-free oocytes were analyzed for poly-(A) mRNA contents and relative mRNA expression of genes involved in cell cycle regulation (cyclin B1 and $\mathrm{H} 1$ ) and antioxidative defence (Mn-superoxide dismutase and glucose-6-phosphate dehydrogenase). Poly(A) mRNA increased after meiotic inhibition and decreased with IVM completion, both in meiotically arrested and permissively matured oocytes, i.e., matured without previous meiotic arrest. RA dramatically increased poly-(A) mRNA in meiotically arrested oocytes, but more than half of the poly-(A) mRNA disappeared during maturation. Irrespective of oocyte origin, transcripts were detected for all the genes analyzed. IVM, with or without previous meiotic inhibition, increased expression of cyclin B1 and glucose-6-phosphate dehydrogenase, and decreased cyclin $\mathrm{H} 1$ and $\mathrm{Mn}$-superoxide dismutase. Except for a decreasing of $\mathrm{Mn}$-superoxide dismutase in meiotically arrested and matured oocytes, RA did not affect mRNA expression. Ethanol led to an abnormal poly(A) mRNA profile and expression of all the genes analyzed. RA does not modify expression of cyclin B1 and $\mathrm{HI}$ genes in the bovine oocyte, and probably does not generate oxidative stress. In addition, RA enhanced mRNA amount as measured by poly-(A) mRNA contents. Mol. Reprod. Dev. 69: 101-108, 2004. (c) 2004 Wiley-Liss, Inc.
\end{abstract}

Key Words: retinoic acid; ethanol; mRNA; polyadenylation; bovine oocyte

\section{INTRODUCTION}

Retinoids are natural and synthetic derivatives of vitamin A (All-trans-retinol; $\mathrm{ROH}$ ) with profound effects on morphogenesis, cell growth and differentiation, vision and reproduction. The $\mathrm{ROH}$ derivative retinoic acid (RA), crucial during vertebrate development, acts as a transcription factor by activating or silencing the expression of hundreds of genes. Embryonic development is a complex process that is extremely sensitive to $\mathrm{ROH}$ since both deficiency and excess can lead to miscarriage or embryonic malformation. The role of retinoids during oocyte development up to pre-blastulation, both in vivo and in vitro, is an unexplored area.

Recently, most of RA nuclear receptors, including $\operatorname{RAR} \alpha$ and $\gamma, \operatorname{RXR} \alpha$ and $\beta$, retinaldehyde dehydrogenase, and peroxisome-proliferator activated receptor gamma (PPAR $\gamma)$, were detected in bovine oocytes and embryos (Mohan et al., 2001, 2002), and in cumulus cells (Mohan et al., 2003). The oocyte's developmental competence is enhanced by retinoid support during oocyte intrafollicular growth in the cow (Shaw et al., 1995), sheep (Eberhardt et al., 1999), and gilt (Whaley et al., 1997; Whaley et al., 2000), as in rabbits that have high levels of vitamin A (Besenfelder et al., 1996). In agreement with these findings, the addition of 9-cis-RA to in vitro maturation (IVM) cultures stimulated cortical granule migration in bovine oocytes both matured (Gómez et al., 2003) and meiotically arrested for a 24-hr culture period (Duque et al., 2002). Increased embryonic development (Duque et al., 2002; Gómez et al., 2003; Hidalgo et al., 2003), embryonic quality (Duque et al., 2002; Hidalgo et al., 2003), cryopreservation tolerance (Duque et al., 2002; Gómez et al., 2003), and pregnancy rates (Hidalgo et al., 2003), were also obtained after oocyte maturation with 9-cis-RA. Recently, we showed increased midkine expression in bovine cumulus-granulosa cells in response to RA (Gómez et al., 2003).

Grant sponsor: Spanish Ministry of Science and Technology; Grant sponsor: FEDER; Grant numbers: AGL2002-01175, AGL2003-05783.

*Correspondence to: Enrique Gomez, SERIDA, Area de Genética y Reproducción Animal, Camino de los Claveles, 604-Somio, Gijón 33203, Spain. E-mail: egomez@serida.org

Received 21 January 2004; Accepted 10 March 2004

Published online in Wiley InterScience (www.interscience.wiley.com) DOI $10.1002 / \mathrm{mrd} .20154$ 
During preovulatory development, events occur rendering the oocyte developmentally competent (Hyttel et al., 1997; Fouladi Nashta et al., 1998). In vitro procedures deprive the cultured oocyte of this period. Molecular events regulating oocyte developmental competence are unknown, but it is thought that the ooplasm stores mRNA and proteins to provide maternal control for development before the embryonic genome is activated. Most transcriptional activity in the oocyte must occur before maturation, but transcription is not fully abolished within the first hours after meiotic resumption (Hyttel et al., 1997; Pavlok et al., 2000; Tomek et al., 2002). Maintenance of reversible meiotic arrest in vitro at the germinal vesicle stage is feasible in cattle by using a variety of chemicals including roscovitine (Mermillod et al., 2000; Lattanzi et al., 2003), a selective inhibitor of cyclin-dependent kinases (Cdks). Roscovitine enables bovine oocytes to be cultured under meiotic inhibition without decreasing their capacity to develop.

Eukaryotic mRNA precursors are processed by five mechanisms: (1) $5^{\prime}$ capping; (2) editing, i.e., conversion of individual RNA residues to alternative bases; (3) $3^{\prime}$ polyadenylation (poly-(A)) cleavage; (4) RNA splicing; and (5) degradation. With the exception of editing, each of these processes have been shown to be co-transcriptional, at least some of the time (see Neugebaeuer, 2002, for a review). In animal cells, the majority of mRNAs have a 3 'poly-(A) tail. During oocyte growth, large amounts of mRNA are synthesized and polyadenylated in the nucleus. Following export to the ooplasm, translation in stored poly-(A) mRNA molecules is abolished by poly-(A) shortening. At defined stages during maturation, cytoplasmic poly-(A) elongation activates mRNA molecules coding for a variety of gene products including those that drive the onset and progression of meiosis (Vassalli and Stutz, 1995). PolyA tails have been shown to regulate both translation and mRNA stability. Requirements for IVM include polyadenylation of mRNAs coding proteins for chromatin condensation, spindle assembly, and activation of MPF and MAP kinase (Krischek and Meinecke, 2002).

The beneficial effect of vitamin A during oocyte growth in vivo has been reproduced by retinol derivatives added to an in vitro culture system in which the oocytes are meiotically arrested (Duque et al., 2002). As a transcription factor, RA can activate or silence a wide number of genes, thus inducing differentiation in many cell systems as well as playing a role in controlling events during the cell cycle (Chao et al., 1997; Zhu et al., 1997; Eto, 1998). In addition, RA seems to have a role in the generation of oxidative stress in the cell (CastroObregon and Covarrubias, 1996; Mantymaa et al., 2000; Ahlemeyer et al., 2001). However, most of the available information about retinoids is related to advanced stages of embryonic development, and little is known about the RA-dependent gene expression and posttranscriptional modifications in the oocyte.

The aim of this study was to analyze molecular mechanisms by which the RA could be acting on the bovine oocyte. Thus, mRNA stability (polyadenylation), expression of genes involved in cell cycle regulation (cyclin B1 and cyclin H1), and expression of genes involved in oxidative damage neutralization (Mn-superoxide dismutase-MnSOD and glucose-6-phosphate dehydrogenase-G6PDH) was analyzed in bovine oocytes during meiotic arrest and/or maturation after RA exposure.

\section{MATERIALS AND METHODS}

All chemicals were purchased from Sigma (Madrid, Spain), unless otherwise indicated.

\section{Collection of COCs}

Ovaries recovered from slaughtered cows were placed in $\mathrm{NaCl}$ solution $\left(9 \mathrm{mg} \mathrm{ml}^{-1}\right)$ containing antibiotics (penicillin, $100 \mathrm{UI} \mathrm{ml}^{-1}$ and streptomycin sulfate, $100 \mu \mathrm{g}$ $\mathrm{ml}^{-1}$ ) and maintained at $25-30^{\circ} \mathrm{C}$ within 2 to $3 \mathrm{hr}$ until COCs collection. Ovaries were washed twice in distilled water and once in freshly prepared saline. Visible follicles of 2-7 $\mathrm{mm}$ in size were aspirated through an 18-gauge needle connected to a syringe, and the contents recovered into a $50 \mathrm{ml}$ plastic tube. Follicular fluid and COCs were placed in an ovum concentrating device (Comextrade, Tarragona, Spain) and rinsed three times with holding medium (HM: TCM199-Invitrogen, Barcelona, Spain-, $25 \mathrm{mM}$ HEPES and BSA $0.5 \mathrm{mg} \mathrm{ml}^{-1}$ ) supplemented with $2 \mathrm{IU} \mathrm{ml}^{-1}$ of heparin.

\section{In Vitro Meiotic Inhibition and Maturation}

Oocytes enclosed in compact cumulus with an evenly granulated cytoplasm were selected and washed three times in HM. Those COCs assigned to groups undergoing meiotic inhibition were washed twice in basic medium (BM: TCM199 + PVA $0.5 \mathrm{mg} \mathrm{ml}^{-1}$ ) containing $25 \mu \mathrm{M}$ roscovitine previously dissolved in $50 \mathrm{mM}$ DMSO and stored in aliquots at $-20^{\circ} \mathrm{C}$. Once thawed, the stock solution was diluted to $10 \mathrm{mM}$ in DMSO before use, as described by Mermillod et al. (2000). Meiotic inhibition was performed by culturing COCs in BM with $25 \mu \mathrm{M}$ roscovitine for $24 \mathrm{hr}$. Those COCs cultured under permissive maturation conditions were washed three times in HM and twice in BM. IVM was carried out in $\mathrm{BM}$ containing pFSH $\left(1 \mu \mathrm{g} \mathrm{ml}^{-1}\right)$, LH $\left(5 \mu \mathrm{g} \mathrm{ml}^{-1}\right)$, and $17 \beta$-estradiol $\left(1 \mu \mathrm{g} \mathrm{ml}^{-1}\right)$ for $24 \mathrm{hr}$. Meiotically arrested COCs were allowed to mature for $24 \mathrm{hr}$ under permissive, nonmeiotically inhibiting conditions. Incubation was performed in four-well dishes (Nunc, Biocen, Spain) containing $500 \mu \mathrm{l}$ of culture medium at $39^{\circ} \mathrm{C}$ in a $5 \%$ $\mathrm{CO}_{2}$ atmosphere and high humidity. For use in culture, 9-cis-RA was dissolved in ethanol to a final concentration in culture of $1 \%$, aliquoted, and stored in darkness at $-80^{\circ} \mathrm{C}$.

\section{RNA Extraction and Reverse Transcription}

Cumulus-granulosa cells were carefully detached from experimental groups of 10 oocytes using $0.05 \%$ hyaluronydase and repeated pipeting. Subsequently, oocytes were stored in RNA-later (Ambion ${ }^{\circledR}$ ), kept overnight at $+4^{\circ} \mathrm{C}$, and stored frozen at $-80^{\circ} \mathrm{C}$ until RNA isolation. Poly(A) RNA was prepared from 4- 
5 pools of 10 oocytes, following the manufacturer's instructions of Dynabeads mRNA Direct KIT (DYNAL). Briefly, samples were lysed in $50 \mu \mathrm{l}$ lysis/binding buffer (DYNAL). After vortexing and brief centrifugation, the samples were incubated at room temperature for $10 \mathrm{~min}$. Ten microliters of prewashed Dynabeads oligo (dT)25 were added to each sample. After 5 min of hybridization, beads were separated from the binding buffer using the Dynal magnetic separator. Beads were then washed in buffer A and B (DYNAL) and the poly(A) RNA was eluted from them by adding $11 \mu \mathrm{l}$ of DEPC-treated water. The resulting poly(A) mRNA was used for reverse transcription (RT) in a total volume of $20 \mu \mathrm{l}$ using $2.5 \mu \mathrm{M}$ random hexamer primer, $1 \times$ RT buffer, 20 IU RNase inhibitor, $50 \mathrm{IU}$ MuLV reverse transcriptase enzyme (Roche, Barcelona, Spain), $5 \mathrm{mM} \mathrm{MgCl} 2$, and $1 \mathrm{mM}$ of each dNTP. Tubes were heated at $70^{\circ} \mathrm{C}$ for $5 \mathrm{~min}$ to denature the secondary RNA structure before the addition of the RT. The RT reaction was incubated at room temperature for $10 \mathrm{~min}$ and subsequently at $42^{\circ} \mathrm{C}$ for $60 \mathrm{~min}$ to allow the RT of RNA, followed by a $1 \mathrm{~min}$ incubation at $93^{\circ} \mathrm{C}$ to denature the $\mathrm{RT}$ enzyme.

\section{Poly(A)mRNA Quantification}

Poly(A)mRNA quantification was determined following the manufacturer's instructions of Poly(A) mRNA Detection System (Promega, Madrid, Spain). Briefly, the poly(A) mRNA quantification based on the pyrophosphorylation property of the DNA polymerase Klenow producing ATP in proportion to the number of poly(A) tails. ATP production was quantified by luminometric assay. mRNA extracted from $4-5$ pools of 10 denuded oocytes from each treatment were submitted to the assay. Anchored oligo(dT) primers were used to hybridize mRNA poly(A) tails. The anchored oligo(dT) primers were 18 mers that had a single deoxyguanosine, deoxycytidine, or deoxyadenosine base at the $3^{\prime}$-end. This base at the $3^{\prime}$-end serves to direct and "anchor" the oligonucleotide to the very start of the poly(A) tail and ensures that only properly anchored oligo(dT) primers will be pyrophosphorylated. Comparison to the number of light units produced by reactions containing known amounts of a standard mRNA were used to estimate the number of mRNA molecules present in unknown samples.

\section{Quantitative Real Time PCR}

For the comparison of the mRNA transcript abundance, PCR was performed using a Rotorgene 2000 Real Time Cycler ${ }^{\mathrm{TM}}$ (Corbett Research, Sydney, Australia) and SYBR Green (Molecular Probes, Eugene, OR) as a double-stranded DNA-specific fluorescent dye. The PCR reaction mixture $(25 \mu \mathrm{l})$ contained $2.5 \mu \mathrm{l} 10 \times$ buffer, $3 \mathrm{mM} \mathrm{MgCl} 2,2 \mathrm{U}$ Taq Express (MWGAG Biotech, Ebersberg, Germany), $100 \mu \mathrm{M}$ of each dNTPs, and $0.2 \mu \mathrm{M}$ of each primer. In addition, the double-stranded DNA dye, SYBR Green I (1:3,000 of a 10,000× stock solution) was included in each reaction. The PCR protocol included an initial step of $94^{\circ} \mathrm{C}(2 \mathrm{~min})$, followed by 40 cycles of $94^{\circ} \mathrm{C}(15 \mathrm{sec}), 56-59^{\circ} \mathrm{C}(30 \mathrm{sec})$, and $72^{\circ} \mathrm{C}$ (30 sec). Fluorescence data was acquired at $85^{\circ} \mathrm{C}$. The melting protocol consisted of holding for $60 \mathrm{sec}$ at $40^{\circ} \mathrm{C}$, followed by heating steps from 50 to $94^{\circ} \mathrm{C}$, and holding at each temperature for 5 sec while monitoring fluorescence. Product identity was confirmed by ethidiumbromide-stained $2 \%$ agarose gel electrophoresis. Tubes were prepared without RNA or reverse transcriptase as negative controls for the quantitative PCR.

The comparative CT method was used for quantification of expression levels (ABI Prism Sequence Detection System User Bulletin No. 2. Foster City, CA: PE Applied Biosystems: 11-14). The quantification was normalized to the endogenous control Histone H2a. Fluorescence was acquired in each cycle to determine the threshold cycle, or the cycle at which the log-linear phase of the fluorescence reaction rose above background for each sample. Within this region of the amplification curve, each difference of one cycle is equivalent to a doubling of the amplified product of the PCR. According to the comparative CT method the $\Delta \mathrm{CT}$ value was determined by subtracting the H2a CT value for each sample from the corresponding mRNA CT value of the sample. The calculation of $\Delta \Delta \mathrm{CT}$ involved using the highest sample $\Delta \mathrm{CT}$ value (i.e., the sample with the lower target expression) as an arbitrary constant to subtract from all other $\Delta \mathrm{CT}$ sample values. Fold changes in the relative gene expression of target was determined by using the formula, $2-\Delta \Delta \mathrm{CT}$. Primer sequences, annealing temperature, the approximate sizes of the amplified fragments, and the Gene Bank accession number are shown in Table 1.

\section{Experimental Design}

Gene expression analysis for cyclin B1, cyclin H1, MnSOD, and G6PDH, and mRNA polyadenylation was analyzed in oocytes. Cultures were as follows.

Experiment 1. Untreated (i.e., without 9-cis-RA and ethanol) immature, meiotically arrested, meiotically arrested-matured, and permissively matured oocytes were analyzed to plot the referential polyadenylation and gene expression profiles of cyclin B1, cyclin $\mathrm{H} 1, \mathrm{G} 6 \mathrm{PDH}$, and MnSOD during the sequence immature-meiotic arrest-maturation.

Experiment 2. The effects of the presence of 9-cisRA on mRNA polyadenylation and gene expression of cyclin B1, cyclin $\mathrm{H} 1, \mathrm{G} 6 \mathrm{PDH}$, and MnSOD were analyzed as follows: (1) after meiotic inhibition; (2) after permissive IVM; and (3) after IVM with oocytes meiotically arrested without additives. Oocytes were treated with 9-cis-RA $5 \mathrm{nM}$ or $1 \%$ ethanol (vehicle) as a negative control.

Data were analyzed by ANOVA and Duncan's test, and expressed as least square mean \pm standard error.

\section{RESULTS}

The experiments were replicated four times, each corresponding to a batch of ovaries.

\section{Experiment 1}

Irrespective of the oocyte origin, transcripts for all the genes analyzed were detected. Poly-A RNA concentra- 
TABLE 1. Details of Primers Used for Quantitative Real Time PCR

\begin{tabular}{|c|c|c|c|c|c|}
\hline Gene & Primer & Sequence $\left(5^{\prime}-3^{\prime}\right)$ & $\begin{array}{l}\text { Fragment } \\
\text { size }(b p)\end{array}$ & $\begin{array}{c}\text { Annealing } \\
\text { temperature }\left({ }^{\circ} \mathrm{C}\right)\end{array}$ & $\begin{array}{l}\text { Gene Bank } \\
\text { accession No. }\end{array}$ \\
\hline Histone $\mathrm{H} 2 \mathrm{a}$ & $5^{\prime}$ & AGGACGACTAGCCATGGACGTGTG & 208 & 59 & NM_174809 \\
\hline Cyclin B1 & $\begin{array}{l}3^{\prime} \\
5^{\prime} \\
3^{\prime}\end{array}$ & $\begin{array}{l}\text { CCACCACCAGCAATTGTAGCCTTG } \\
\text { ATGTGGATGCAGAAGACGGAG } \\
\text { CCGCTGCAATCTGAGAAGGAG }\end{array}$ & 576 & 55 & L26548.1 \\
\hline Cyclin $\mathrm{H}$ & $\begin{array}{l}5^{\prime} \\
3^{\prime}\end{array}$ & $\begin{array}{l}\text { CGGTCTGTTGTGGGTACAGCTTG } \\
\text { TCGATGAGGAAGCCTTCAAATGG }\end{array}$ & 290 & 55 & BC038861 \\
\hline MnSOD & $\begin{array}{l}5^{\prime} \\
3^{\prime}\end{array}$ & $\begin{array}{l}\text { CCCATGAAGCCTTTCTAATCCTG } \\
\text { TTCAGAGGCGCTACTATTTCCTTC }\end{array}$ & 307 & 56 & L2292.1 \\
\hline G6PDH & $\begin{array}{l}5^{\prime} \\
3^{\prime}\end{array}$ & $\begin{array}{l}\text { CGCTGGGACGGGGTGCCCTTCATC } \\
\text { CGCCAGGCCTCCCGCAGTTCATCA }\end{array}$ & 347 & 56 & XM_0493 \\
\hline
\end{tabular}

tion in the untreated oocyte increased after meiotic inhibition and decreased upon IVM completion, both in meiotically arrested and nonmeiotically arrested oocytes $(P<0.01)$ (Fig. 1a). Gene expression sequential changes can be observed in Figure 2. In vitro matured oocytes, in both permissive and meiotic inhibition conditions, display increased expression of cyclin B1 (Fig. 2a) and G6PDH (Fig. 2d), and decreased cyclin H1 (Fig. 2b) and MnSOD (Fig. 2c), when compared with immature oocytes. To a lesser extent, these changes could already be observed after meiotic inhibition. Values for cyclin B1, cyclin $\mathrm{H} 1$, and MnSOD, recorded after meiotic arrest followed by maturation, were higher than those from meiotically arrested oocytes; these differences were not observed for G6PDH. Oocytes submitted to permissive maturation showed levels of G6PDH and MnSOD respectively higher and lower than their counterparts matured in nonpermissive conditions.

\section{Experiment 2}

As shown in Figure 1b, poly-(A) mRNA levels increased dramatically in oocytes meiotically arrested in medium with 9-cis-RA. However, no RA-dependent changes were observed in oocytes exposed to permissive IVM. Oocytes that matured in the presence of RA after a meiotic inhibition period showed reduced poly-(A) contents. Control oocytes, exposed to $1 \%$ ethanol, did not follow the pattern of untreated oocytes (Fig. 1a), since immature oocytes and oocytes meiotically arrested treated with ethanol exhibited similar poly-(A) mRNA contents (Fig. 1b).

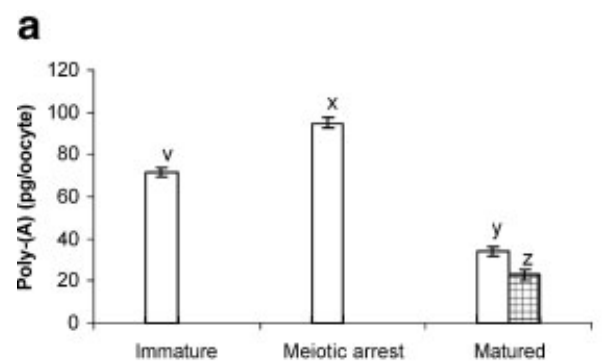

Fig. 1. Poly-(A) RNA profile in the bovine oocyte. a: Cultures performed without additives (no 9-cis-RA and no ethanol), are represented by open bars within the immature $>$ meiotic arrest $>$ maturation sequence, while the squared bar corresponds to in vitro maturation without meiotic arrest. b: Cultures start from immature oocytes (open bar), treated
The presence of 9-cis-RA during IVM of meiotically arrested oocytes led to a decreased expression of the MnSOD gene (Fig. 3c). This was the only effect attributable to 9-cis-RA that we could observe in this study on expression within the four genes analyzed. However, the presence of the vehicle ethanol significantly altered gene expression in oocytes, as made apparent by the abnormal changing pattern of expression between stages. In the presence of ethanol, cyclin B1 decreased during IVM in meiotically arrested oocytes, and cyclin H1 increased with both IVM types. Expression of MnSOD was higher in oocytes meiotically arrested with vehicle, and subsequent IVM did not show appreciable differences in comparison with immature oocytes. Finally, in oocytes meiotically arrested and matured, G6PDH expression was significantly decreased.

\section{DISCUSSION}

The increase in poly-(A) mRNA, observed in this study, during oocyte meiotic inhibition in the presence of RA, may explain the observed gain in developmental competence and oocyte quality after RA treatment (Duque et al., 2002). In the course of bovine IVM, the length of poly-(A) tails for cyclins B1 and B2 were reported to increase (Lastro et al., 1999). In our study, polyadenylation levels peaked in meiotically arrested oocytes, and showed decreases after IVM, which is consistent with a shortening of poly-(A) tails as reported with most genes analyzed in oocytes matured in vitro (Brevini-Gandolfi et al., 1999). These findings are in

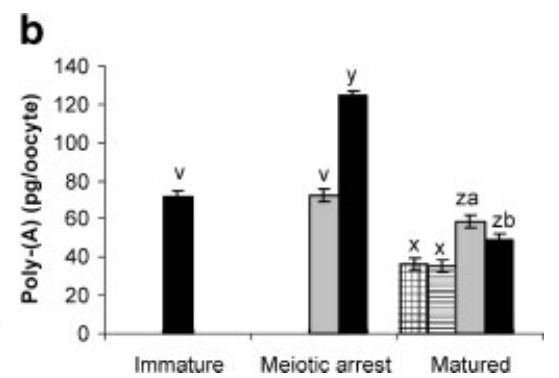

with 9-cis-RA (solid bars) or the vehicle 1\% ethanol (grey bar), throughout the immature $>$ meiotic arrest $>$ maturation sequence, or correspond to oocytes matured without meiotic arrest with $1 \%$ ethanol (squared bar) or 9-cis-RA (lined bar). Superscripts express significant differences ${ }^{\mathrm{a}, \mathrm{b}}(P<0.05)$; $^{\mathrm{v}, \mathrm{x}, \mathrm{y}, \mathrm{z}}(P<0.01)$. 


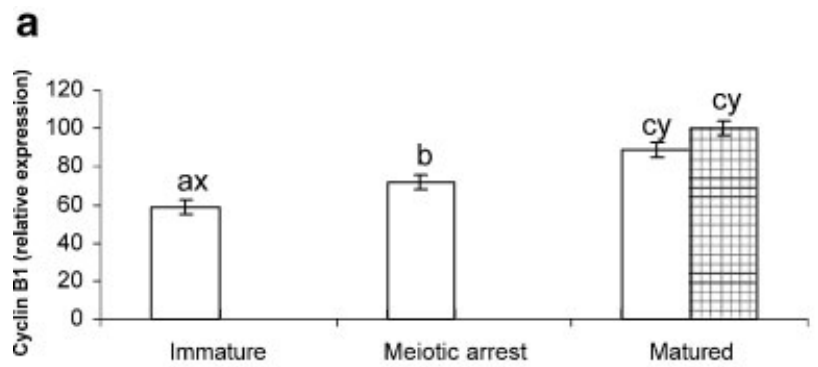

b

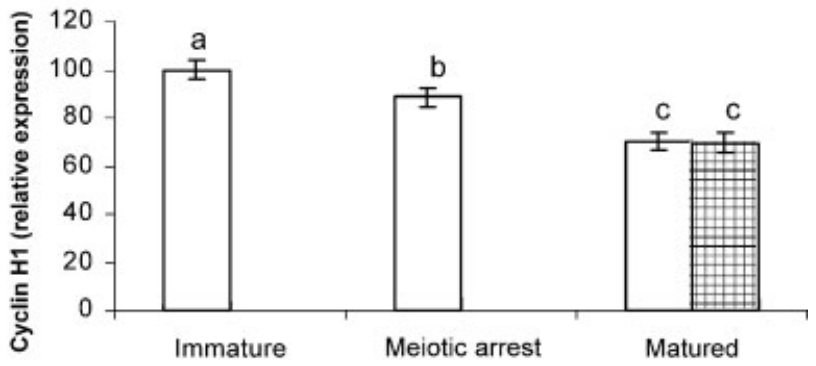

d

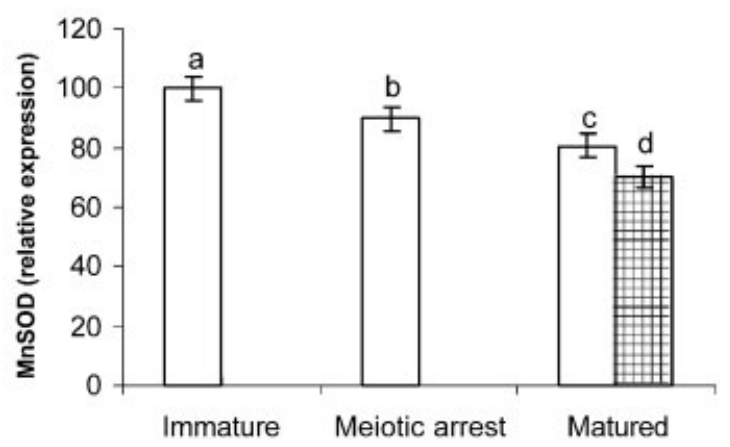

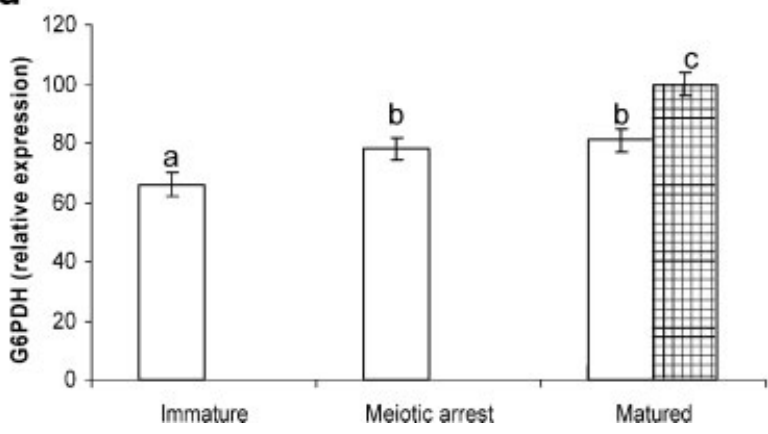

Fig. 2. Expression of genes involved in cell cycle control (a: Cyclin B1; b: Cyclin H1) and repairing oxidative damage (c: MnSOD; d: G6PDH) in the bovine oocyte developed without additives (no 9-cis-RA and no ethanol) throughout the culture period. Open bars correspond to the immature $>$ meiotic arrest $>$ maturation sequence, and squared bars correspond to oocytes matured without meiotic arrest. Superscripts express significant differences ${ }^{\mathrm{x}, \mathrm{y}}(P<0.01){ }^{\mathrm{a}, \mathrm{b}, \mathrm{c}}(P<0.05)$.

contrast with a recently described poly-(A) mRNA accumulation until metaphase II (Tomek et al., 2002) and with no apparent changes in poly-A-polymerase transcripts abundance during IVM (Gómez et al., 2003). Upon a 9-cis-RA treatment, poly-(A) dramatically increased after meiotic arrest and decreased when these oocytes matured in vitro. The amount of poly-A in the oocyte is associated with a gain in the quality of mRNA stored in the ooplasm (Lonergan et al., 2003a), and defective developmental competence is accompanied by abnormal polyadenylation levels (Brevini et al., 2002).

To our knowledge, there is no published evidence of direct links between mRNA polyadenylation levels and retinoid stimulation. However, it is not surprising that increased gene expression occurs with enhanced mRNA processing, since proteins that catalyze polyadenylation are associated with RNA polymerase II (Pol II), providing a link between transcription and formation of the $3^{\prime}$ end of mRNA (Maniatis and Reed, 2000; Proudfoot et al., 2000). A functional polyadenylation signal terminates transcription and release Pol II (Whale and Ruegsegger, 1999; Shatkin and Manley, 2000), although polyadenylation seems to continue post-transcriptionally (Osheim et al., 1999, 2002).

Ethanol altered poly-(A) contents in oocytes, as occurred with gene expression, and importantly abol- ished the poly-(A) rise after meiotic arrest. Ethanol decreases RA synthesis in competition with retinol to inhibit the alcohol-dehydrogenase (Duester, 1991; Duester et al., 1991). In addition, RA can be degraded by ethanol inducible CYP2E1, a P450 metabolizing RA, to more polar metabolites in vitro (Liu et al., 2001). This process would need days or weeks of treatment to occur, which does not correspond to our experimental conditions. In fact, ethanol did reduce endogenous RA concentrations in cultured mouse embryos (Deltour et al., 1996). However, we previously demonstrated that $1 \%$ ethanol does not stimulate parthenogenetic activation (Hidalgo et al., 2003).

Our study showed that in the absence of 9-cis-RA, the meiotic inhibition by roscovitine raised cyclin B1 and lowered cyclin H1. These changes were enhanced both after subsequent IVM and within permissive conditions. The meiotic inhibition by roscovitine essentially affects cdc2, Cdk2, and Cdk5 in competition with ATP (De Azevedo et al., 1997; Meijer et al., 1997). The cyclin H/ Cdk7 complexes controls cell cycle as a Cdk-activating kinase (CAK) (Fisher and Morgan, 1994). In male germ cells, H/Cdk7 complex are present during meiosis and may activate cyclin A1-associated kinase (Kim et al., 2001), which are likely to be upstream of the final activation of the cyclin B1/Cdk1 kinase (Liu et al., 2000), 
a

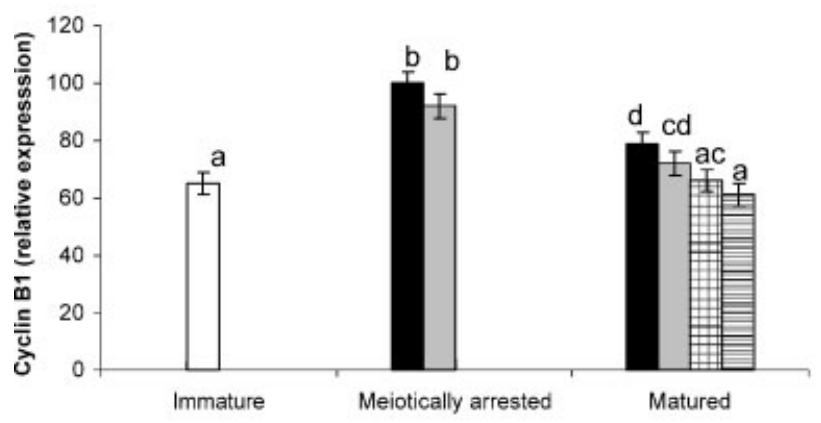

C

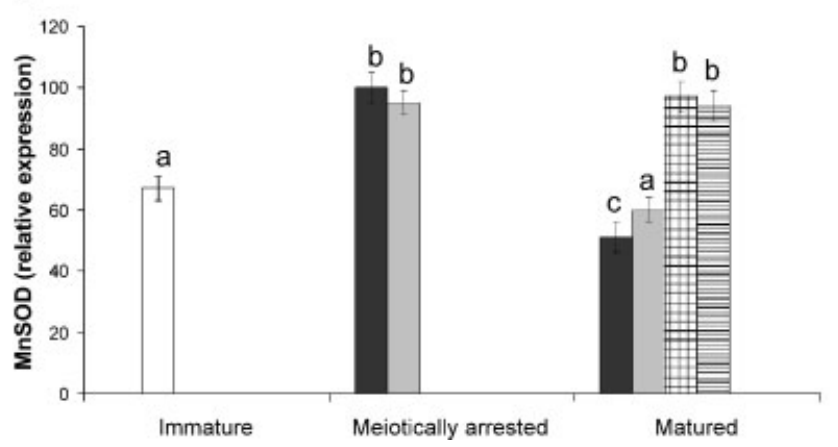

b

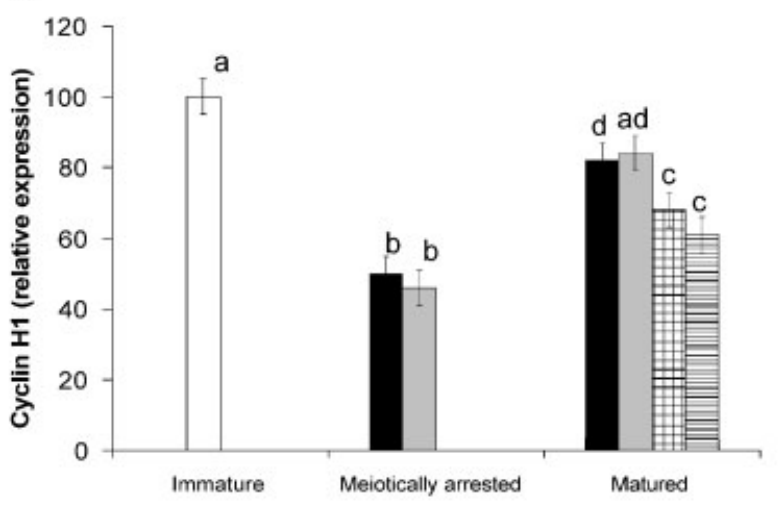

d

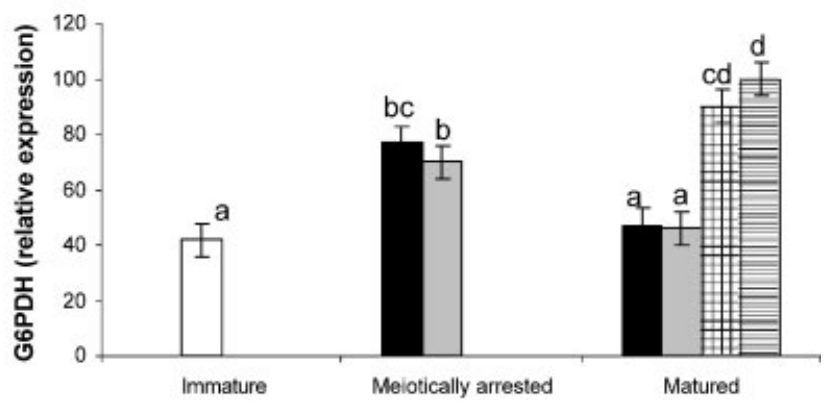

Fig. 3. Relative gene expression of cyclin B1 (a), cyclin H1 (b), MnSOD (c), and G6PDH (d) in oocytes. Cultures start from immature oocytes (open bar), treated with 9-cis-RA (solid bars) or the vehicle 1\% ethanol (grey bar), throughout the immature $>$ meiotic arrest $>$ maturation sequence, or correspond to oocytes matured without meiotic arrest with $1 \%$ ethanol (squared bar) or 9-cis-RA (lined bar). Superscripts express significant differences: ${ }^{\text {a,b,c,d }}(P<0.05)$.

and are essential for meiosis (Zhu et al., 1997). Accumulation of cyclin B1 transcripts were found in bovine oocytes matured in vivo but not in oocytes matured in vitro in the presence of serum (Lonergan et al., 2003a), in contrast to our findings in oocytes matured in chemically defined conditions. Levesque and Sirard (1996) did not find immunodetected cyclin B1 in bovine oocytes until meiotic resumption, but our results are in agreement with authors that detected transcripts for cyclins in immature oocytes (Winston, 2001; Vigneron et al., 2002). Some cell types show inhibition of cyclin B1 (Chao et al., 1997; Zhu et al., 1997; Eto, 1998) and cyclin A1 (Chao et al., 1997; Eto, 1998) by treatment with RA, in contrast with the lack of effect of 9-cis-RA on cyclins found in our analysis. This could be explained as a precocious release of Pol II due to increased polyadenylation induced by RA, which would lead to transcriptional drop.

RA did not increase expression levels of MnSOD and G6PDH in the oocyte. As a consequence, it can be inferred that the addition of RA did not promote oxidative stress. The enzyme MnSOD is an oxygen free radical scavenger that typically increases in response to RA-induced oxidative stress (CastroObregon and Covarrubias, 1996; Mantymaa et al., 2000;
Ahlemeyer et al., 2001). Therefore, expression of MnSOD is not directly regulated by RA signaling, but by a response to the oxidative environment generated by the RA in the cell. In this study, levels of MnSOD steadily decreased from immature oocytes through meiotically inhibited oocytes to matured oocytes, with MnSOD being higher in oocytes undergoing IVM after meiotic arrest. In the presence of RA, expression of MnSOD did not change during meiotic inhibition, but decreased after IVM subsequent to meiotic inhibition.

G6PDH is the first and rate-limiting enzyme in the pentose phosphate pathway and is responsible for the generation of NADPH. Protection against reactive oxygen species requires maintenance of endogenous thiol pools, and most importantly, reduced glutathione (GSH) by NADPH. Early investigations on the enzyme G6PDH indicated that the protein is inhibited in cells by RA (Raab and Gmeiner, 1976; Mukherjee et al., 1990) and certain synthetic analogs (Berset and Krebs, 1990). On the other hand, RA is able to induce differentiation in cells such as U-937, a human monoblastic cell line, by increasing mRNA levels for G6PD (Yamazaki and Birnboim, 1995). In the absence of RA, expression of G6PDH, according to our study, increased within meiotically arrested oocytes when compared to imma- 
ture ones. Nevertheless, mRNA G6PDH levels did not increase once meiotically inhibited oocytes were allowed to mature in vitro. In contrast, permissive IVM led to higher levels of G6PDH mRNA expression. In the presence of 9-cis-RA, G6PDH levels did not change in meiotically arrested and/or matured oocytes.

In cattle, gene expression of MnSOD (Lequarre et al., 2001; Lonergan et al., 2003a) and G6PDH (Liu et al., 2000) was found in immature and in vitro matured oocytes (Lequarre et al., 2001; Lonergan et al., 2003a). However, Lonergan et al. (2003a) found similar abundance of both gene transcripts between in vitro matured and immature oocytes from slaughterhouse ovaries. In contrast, oocytes matured in vitro, recovered just before the LH surge, and oocytes matured in vivo, showed decreased MnSOD and increased G6PDH, in agreement with our results.

This study revealed that the model of gene expression and processing from oocytes permissively matured is not the same in oocytes matured after a meiotic inhibition period. In fact, although cyclin B1 and cyclin $\mathrm{H} 1$ had a similar performance, the existence of meiotic inhibition before IVM affected polyadenylation and gene expression of G6PDH and MnSOD. The presence of meiotic inhibitors is likely to allow neo-transcription or polyadenylation of pre-existing mRNAs or both. The implications of these findings in subsequent oocyte developmental ability are unknown, although roscovitine alone does not reduce the potential of oocyte development (Mermillod et al., 2000; Lattanzi et al., 2003). However, the differences we observed in the inhibited oocyte at the transcription level, as well as ultrastructural anomalies (Lonergan et al., 2003b), coexist with normal or improved embryonic development.

The gene sequences activated or repressed by RA at meiotic arrest, leading to increased polyadenylation, could therefore explain part of the effects on development observed in former oocyte studies (Duque et al., 2002; Gómez et al., 2003; Hidalgo et al., 2003). These changes included increased expression in granulosa cells of midkine (Gómez et al., 2003), a retinoid responsive gene, whose recombinant peptide product stimulates embryonic development in vitro up to the blastocyst stage (Ikeda et al., 2000a,b).

The developmental competence of the bovine oocyte is stimulated by 9-cis-RA (Duque et al., 2002; Gómez et al., 2003; Hidalgo et al., 2003), while micromolar concentrations suppress embryo development (Gómez et al., 2003). In addition, after comparing our gene expression profile found for Cyclin B1, MnSOD, and G6PDH with a previous study using a serum-supplemented maturation medium (Lonergan et al., 2003a), it is again demonstrated that serum yields artifacts. In response to RA, the bovine oocyte does not modify expression of cyclins B1 and HI genes, essential regulators of cell cycle, and the retinoid is unlikely to generate oxidative stress. Instead, the higher polyadenylation observed, suggests increased mRNA quality as well as increased processing. Whether enhanced polyadenylation is a reflection of higher gene expression remains intriguing.
Therefore, assessment of expression of gene sequences other than those analyzed in this study will be accomplished in the future on the basis of their responsiveness to RA. In addition, and given the inhibitory effect of ethanol on the retinoid metabolism, the retinoid pathway was revealed to be an important tool to control differentiation and possibly embryonic stem cell maintenance. This represents an important goal and challenge in bovine biotechnology.

\section{ACKNOWLEDGMENTS}

Nieves Facal and Ivan Fernandez provided excellent technical assistance.

\section{REFERENCES}

Ahlemeyer B, Bauerbach E, Plath M, Steuber M, Heers C, Tegtmeier F, Krieglstein J. 2001. Retinoic acid reduces apoptosis and oxidative stress by preservation of SOD protein level. Free Radic Biol Med 30:1067-1077.

Berset JD, Krebs A. 1990. Synthesis and characterization of new 10acylderivatives of the antipsoriatic agent dithranol: Coupling products of dithranol with all-trans-retinoic acid, 13-cis-retinoic acid and an aromatic analogue of retinoic acid: all-trans-9-(4-methoxy2,3,6-trimethylphenyl)-3,7-dimethyl-nona-2,4,6,8-tetraenoate. Pharm Acta Helv 65:290-297.

Besenfelder UL, Solti J, Seregi M, Müller M, Brem G. 1996. Different roles for B-carotene and vitamin $\mathrm{A}$ in the reproduction of rabbits. Theriogenology 45:1583-1591.

Brevini TA, Lonergan P, Cillo F, Francisci C, Favetta LA, Fair T, Gandolfi F. 2002. Evolution of mRNA polyadenylation between oocyte maturation and first embryonic cleavage in cattle and its relation with developmental competence. Mol Reprod Dev 63:510517.

Brevini-Gandolfi TA, Favetta LA, Mauri L, Luciano AM, Cillo F, Gandolfi F. 1999. Changes in poly (A) tail length of maternal transcripts during in vitro maturation of bovine oocytes and their relation with developmental competence. Mol Reprod Dev 52:427433.

Castro-Obregon S, Covarrubias L. 1996. Role of retinoic acid and oxidative stress in embryonic stem cell death and neuronal differentiation. FEBS Lett 381:93-97.

Chao TY, Jiang SY, Shyu RY, Yeh MY, Chu TM. 1997. All-trans retinoic acid decreases susceptibility of a gastric cancer cell line to lymphokine-activated killer cytotoxicity. Br J Cancer 75:1284-1290.

De Azevedo WF, Leclerc S, Meijer L, Havlicek L, Stmad M, Kim SH 1997. Inhibition of cyclin-dependent kinases by purine analogues: Crystal structure of human cdk2 complexed with roscovitine. Eur J Biochem 243:518-526.

Deltour L, Ang HL, Duester G. 1996. Ethanol inhibition of retinoic acid synthesis as a potential mechanism for fetal alcohol syndrome. FASEB J 10:1050-1057.

Duester G. 1991. A hypothetical mechanism for fetal alcohol syndrome involving ethanol inhibition of retinoic acid synthesis at alcohol dehydrogenase step. Alcohol Clin Exp Res 15:568-572.

Duester G, Shean ML, Mcbride MS, Stewart MJ. 1991. Retinoic acid response element in the human alcohol dehydrogenase gene $A D H 3$ : Implications for regulation of retinoic acid synthesis. Mol Cell Biol 11:1638-1646.

Duque P, Díez C, Royo LJ, Lorenzo PL, Carneiro G, Hidalgo CO, Facal N, Gómez E. 2002. Enhancement of developmental capacity of meiotically inhibited bovine oocytes by retinoic acid. Hum Reprod 17:2706-2714.

Eberhardt DM, Will WA, Godkin JD. 1999. Retinol administration to superovulated ewes improves in vitro embryonic viability. Biol Reprod 60:1483-1487.

Eto I. 1998. Promotion-sensitive epidermal and mammary epithelial cells maintained in suspension over agarose. Cell Prolif 31:71-92.

Fisher RP, Morgan DO. 1994. A novel cyclin associates with MO15/ CDK7 to form the CDK activating kinase. Cell 78:713-724. 
Fouladi Nashta AA, Waddington D, Campbell KHS. 1998. Maintenance of bovine oocytes in meiotic arrest and subsequent development in vitro: A comparative evaluation of antral follicle culture with other methods. Biol Reprod 59:255-262.

Gómez E, Royo LJ, Duque P, Carneiro G, Hidalgo C, Goyache F, Lorenzo P, Alvarez I, Facal N, Díez C. 2003. 9-cis-retinoic acid during in vitro maturation improves development of the bovine oocyte and increases midkine but not IGF-I expression in cumulus-granulosa cells. Mol Reprod Dev 66:247-255.

Hidalgo CO, Díez C, Duque P, Facal N, Gómez E. 2003. Pregnancies and improved early embryonic development in bovine oocytes matured in vitro with 9-cis-retinoic acid. Reproduction 125:409-416.

Hyttel P, Fair T, Callesen H, Greve T. 1997. Oocyte growth, capacitation, and final maturation in cattle. Theriogenology 47:3-32.

Ikeda S, Ichihara-Tanaka K, Azuma T, Muramatsu T, Yamada M. 2000a. Effects of midkine during in vitro maturation of bovine oocytes on subsequent developmental competence. Biol Reprod 63: $1067-1074$.

Ikeda S, Nishikimi A, Ichihara-Tanaka K, Muramatsu T, Yamada M. 2000b. cDNA cloning of bovine midkine and production of the recombinant protein, which affects in vitro maturation of bovine oocytes. Mol Reprod Dev 57:99-107.

Kim JM, McGaughy JT, Bogle RK, Ravnik SE. 2001. Meiotic expression of the cyclin $\mathrm{H} / \mathrm{Cdk} 7$ complex in male germ cells of the mouse. Biol Reprod 64:1400-1408.

Krischek C, Meinecke B. 2002. In vitro maturation of bovine oocytes requires polyadenylation of mRNAs coding proteins for chromatin condensation, spindle assembly, MPF and MAP kinase activation. Anim Reprod Sci 73:129-140.

Lane MA, Chen AC, Roman SD, Derguini F, Gudas LJ. 1999. Removal of LIF (leukaemia inhibitory factor) results in increased vitamin A (retinol) metabolism to 4-oxoretinol in embryonic stem cells. Proc Natl Acad Sci USA 96:13524-13529.

Lastro M, Ignotz GG, Currie WB. 1999. Preventing polyadenylation delays but does not prevent maturation of bovine oocytes: Changes in cyclin B1 and B2 transcripts. J Reprod Fertil Abstract Series No. 23: Abstract No 43.

Lattanzi ML, Santos CB, Mudry MD, Baranao JL. 2003. Exposure of bovine oocytes to the endogenous metabolite 2-methoxyestradiol during in vitro maturation inhibits early embryonic development. Biol Reprod 69:1793-1800.

Lequarre AS, Feugang JM, Malhomme O, Donnay I, Massip A, Dessy F, Van Langendonckt A. 2001. Expression of $\mathrm{Cu} / \mathrm{Zn}$ and $\mathrm{Mn}$ superoxide dismutases during bovine embryo development: Influence of in vitro culture. Mol Reprod Dev 58:45-53.

Levesque JT, Sirard MA. 1996. Resumption of meiosis is initiated by the accumulation of cyclin B in bovine oocytes. Biol Reprod 55:14271436

Liu D, Liao C, Wolgemuth DJ. 2000. A role for cyclin A1 in the activation of MPF and G2-M transition during meiosis of male germ cells in mice. Dev Biol 224:388-400.

Liu C, Russell RM, Seitz HK, Wang XD. 2001. Ethanol enhances retinoic acid metabolism into polar metabolites in rat liver via induction of cytochrome P4502E1. Gastroenterology 120:179-189.

Lonergan P, Faerge I, Hyttel PM, Boland M, Fair T. 2003a. Ultraestructural modifications in bovine oocytes maintained in meiotic arrest in vitro using roscovitine or butyrolactone. Mol Reprod Dev 64:369-378.

Lonergan P, Gutierrez-Adan A, Rizos D, Pintado B, De la Fuente J, Boland MP. 2003b. Relative messenger RNA abundance in bovine oocytes collected in vitro or in vivo before and $20 \mathrm{~h}$ after the preovulatory luteinizing hormone surge. Mol Reprod Dev 66:297305 .

Maniatis T, Reed R. 2000. An extensive network of coupling among gene expression machines. Nature 416:499-506.

Mantymaa P, Guttorm T, Siitonen T, Saily M, Savolainen ER, Levonen AL, Kinnula V, Koistinen P. 2000. Cellular redox state and its relationship to the inhibition of clonal cell growth and the induction of apoptosis during all-trans retinoic acid exposure in acute myeloblastic leukaemia cells. Haematologica 85:238-245.

Meijer L, Borgne A, Mulner O, Chong JP, Blow JJ, Inagaki N, Inagaki M, Delcros JG, Moulinoux JP. 1997. Biochemical and cellular effects of roscovitine, a potent and selective inhibitor of the cyclin-dependent kinases cdc2, cdk2, and cdk5. Eur J Biochem 243:527-536.

Mermillod P, Tomanek M, Marchal R, Meijer L. 2000. High developmental competence of cattle oocytes maintained at the germinal vesicle stage for 24 hours in culture by specific inhibition of MPF kinase activity. Mol Reprod Dev 55:89-95.

Mohan M, Malayer JR, Geisert RD, Morgan GL. 2001. Expression of retinol-binding protein messenger RNA and retinoic acid receptors in preattachment bovine embryos. Mol Reprod Dev 60:289-296.

Mohan M, Malayer JR, Geisert RD, Morgan GL. 2002. Expression patterns of retinoid $\mathrm{X}$ receptors, retinaldehyde dehydrogenase, and peroxisome proliferator activated receptor gamma in bovine preattachment embryos. Biol Reprod 66:692-700.

Mohan M, Thirumalapura NR, Malayer J. 2003. Bovine cumulusgranulosa cells contain biologically active retinoid receptors that can respond to retinoic acid. Reprod Biol Endocrinol 1:104.

Mukherjee G, Banerjee D, Bhattacharya DK, Chatterjee GC. 1990 Effect of retinoic acid on adenosine diphosphate and collageninduced alterations in enzymes of GSH-linked antioxidant defence system of human blood platelets in vitro. Indian J Exp Biol 28:550 552 .

Neugebaeuer KM. 2002. On the importance of being co-transcriptional. J Cell Sci 115:3865-3871.

Osheim YN, Proudfoot NJ, Beyer AL. 1999. EM visualization of transcription by RNA polymerase II: Downstream termination requires a poly(A) signal but not transcript cleavage. Mol Cell 3: 379-387.

Osheim YN, Sikes ML, Beyer AL. 2002. EM visualization of Pol II genes in Drosophila: Most genes terminate without prior 3' end cleavage of nascent transcripts. Chromosoma 111:1-12.

Pavlok A, Kanka J, Motlik J, Vodicka P. 2000. Culture of bovine oocytes from small antral follicles in meiosis-inhibiting medium with butyrolactone I: RNA synthesis, nucleolar morphology, and meiotic competence. Anim Reprod Sci 64:1-11.

Proudfoot NJ, Furger A, Dye MJ. 2000. Integrating mRNA processing with transcription. Cell 108:501-512.

Raab WP, Gmeiner BM. 1976. Influences of retinoic acid and retinoid on skin metabolism. Investigations of oxygen consumption and enzymatic activities of human skin. Arch Dermatol Res 256:247-254.

Shatkin AJ, Manley JL. 2000. The ends of the affair: Capping and polyadenylation. Nat Struct Biol 7:838-842.

Shaw DW, Farin PW, Washburn SP, Britt JH. 1995. Effect of retinol palmitate on ovulation rate and embryo quality in superovulated cattle. Theriogenology 44:51-58.

Tomek W, Torner H, Kanitz W. 2002. Comparative analysis of protein synthesis, transcription, and cytoplasmic polyadenylation of mRNA during maturation of bovine oocytes in vitro. Reprod Domest Anim 37:86-91.

Vassalli JD, Stutz A. 1995. Translational control: Awakening dormant mRNAs. Curr Biol 5:476-479.

Vigneron C, Dalbies-Tran R, Guyader-Joly C, Perreau C, Humblot P, Mermillod P. 2002. Expression of cyclin B1 and cdk1 messengers during in vivo maturation and in vitro culture of cattle oocytes. In 18th Scientific Meeting of the European Embryo Transfer Association Rolduc.

Whale E, Ruegsegger U. 1999. $3^{\prime}$ end processing of pre-mRNA in eukaryotes. FEMS Microbiol Rev 23:277-295

Whaley SL, Hedgpeth VS, Britt JH. 1997. Evidence that injection of vitamin A before mating may improve embryo survival in gilts fed normal or high energy diets. J Anim Sci 75:1071-1077.

Whaley SL, Hedgpeth VS, Farin CE, Martus NS, Jayes FC, Britt JH 2000. Influence of vitamin A injection before mating on oocyte development, follicular hormones, and ovulation in gilts fed highenergy diets. J Anim Sci 78:1598-1607.

Winston N. 2001. Regulation of early embryo development: Functional redundancy between cyclin subtypes. Reprod Fertil Dev 13:59-67.

Yamazaki A, Birnboim HC. 1995. Potentiation of retinoic acid-induced U-937 differentiation into respiratory burst-competent cells by nitric oxide donors. Leuk Res 19:325-335.

Zhu D, Dix DJ, Eddy EM. 1997. HSP70-2 is required for CDC2 kinase activity in meiosis 1 of mouse spermatocytes. Development 124 3007-3014. 